\title{
District schools and the erosion of parental rights under the Poor Law: A case study from London 1889-1899 \\ By Rachel Pimm-Smith
}

\begin{abstract}
This article investigates the empirical backing for the claim that poor law officials needed legal authority to refuse poor parents' right to the custody of their children in order to stabilise children's welfare institutions during the nineteenth century. Although workhouses were capable of accommodating children, Victorian lawmakers feared children would model themselves on adult paupers to become permanent burdens on the state. To tackle this problem, a system of children's welfare institutions called 'district schools' was introduced to train children to become industrious adult labourers. Children were usually classified as orphans or deserted so they could be sent to district schools without fear of family intervention. However, children with ambiguous parental circumstances were labelled as 'other' and considered a problematic class because they were perceived to be at risk of having ongoing contact with their birth families. Lawmakers feared parents of 'other' children would undermine reformation efforts by asserting their custody rights and passed the first laws in English history to allow the state to restrict parental rights on this basis. This article explores the claim of unwanted parental involvement, and in doing so, seeks to contextualise the origins of public law interference in the family sphere within a narrative of imposed citizenship rather than protection.
\end{abstract}

\section{Keywords: Parental rights, child welfare, poor law, Victorian poverty}

\section{Introduction}


During the 1870 s and 80 s, social welfare for children was provided in three main ways: through philanthropic organisations, or from the state through direct financial support to parents or by admission to an institution. Philanthropic societies presented themselves as rescue organisations with a primary objective of saving children whose parents had died or deserted them. Some of them are still in operation today, including Barnardo's, the National Society for the Prevention of Cruelty to Children (NSPCC) and The Waifs and Strays Society (now known as the Children's Society). These organisations cared for thousands of children during the late-nineteenth century, predominantly by sending them overseas to countries like Canada or Australia, or placing them in privately funded orphanages such as those operated by Thomas Barnardo. Although these organisations presented themselves as rescue societies for parentless children, modern historians have recently argued that most of the children in their care were in fact not parentless at all. ${ }^{1}$ Research shows that most children in philanthropic care had at least one parent who voluntarily gave up custody of their child in the hopes that a charitable society could offer a better life than the parent could afford.

My wider research shows something very similar was happening in the children's welfare institutions under the control of the poor law authorities during the latenineteenth century - particularly in district schools. ${ }^{2}$ In my doctoral thesis I argued parents were often forced to choose between institutionalising themselves or their children, and that it appears giving school-aged children to the care of the state was a popular coping strategy. ${ }^{3}$ This article critically examines the political discourse surrounding the growing numbers of children in district schools who had known parents living outside the workhouse. Lawmakers disparaged the idea that poor 
parents would sooner admit their children to a district school than submit themselves to the workhouse because lawmakers felt this was an abuse of the system. Throughout the 1870 s and 80 s a discourse developed that was harshly critical of parents with children under the care of the state.

I argue in this article that this discourse provided the crucial link between reductions in welfare throughout the 1870 s and the introduction of the first powers to restrict parental rights in the $80 \mathrm{~s}$. As access to much-needed support was reduced, more vulnerable parents - particularly mothers - gave up their children in desperation. The state responded to this growing burden by curtailing parental custody rights and justified intervention on the basis that parents abused their custody rights to the detriment of their children. This article presents empirical evidence that suggests these claims were heavily overstated, which raises important questions about the legitimacy of original public law interference within parent-child relationships.

\section{The socio-legal landscape behind welfare reductions}

England entered a period of severe recession in the early 1870 s following changes in agricultural trade and the repeal of the Corn Laws. This repeal saw British grain profits fall to record lows, and consequently, rural areas experienced high levels of economic migration and urban populations became increasingly large. Before the recession started, most poor people who needed public assistance were eligible for a form of welfare support called 'outdoor relief'. Outdoor relief could take the form of direct weekly payments, medical extras, clothes and/or food but was designed so that people who were deemed deserving of help could remain in their homes instead of entering the workhouse. Throughout the early to mid-nineteenth century, notions of 
deserving were broadly conceived, which allowed for people from a range of different circumstances to access support from the state. This included lone mothers, widows, deserted wives and women whose spouses had been sent to workhouses or other public institutions.

Outdoor relief was important because it provided an essential form of support for vulnerable mothers to retain custody of their children by allowing them to stay in their communities. The ability to retain a support network was of critical significance to vulnerable mothers because poor women usually experienced additional challenges associated with poverty compared to men. Pat Thane rightly highlights the inability of poor women from this period to earn or save sufficient funds and their greater susceptibility toward destitution at the end of their lives compared to men. ${ }^{4}$ Although men were arguably more able to navigate the misfortunes of poverty at this time than women, they too experienced unique challenges. Men were less eligible for outdoor relief than women and as a result more likely to enter the workhouse. Nigel Goose explains some of the consequences of gender-based welfare policies such as the substantial presence of elderly men in workhouses and men whose lives were reduced to domestic responsibilities following an illness or accident. ${ }^{5}$ Such experiences usually brought shame on families and exacerbated the hardship of material deprivation.

Workhouses were harsh environments where inmates were only provided with relief if they submitted to the principle of 'less eligibility'. This principle required that life inside the workhouse be harder than the life of the lowest paid independent labourer in order to deter those capable of work from relying on the state. ${ }^{6}$ Joseph Harley 
explains how some paupers, of both genders, were able to use workhouses as shortterm coping strategies but that generally it was the most vulnerable who struggled to use this tactic. ${ }^{7}$ I argue that lone mothers with large numbers of children were one of the most vulnerable groups of the poor from this period and that is why so many of them gave up their children instead entering the workhouse themselves.

As the socio-economic landscape changed following the recession, the application of welfare principle did as well. Before the recession started outdoor relief was by far the most common means of distributing welfare in England. Figures from 1871 show that 843,000 people were relieved in their homes, whereas only 140,000 people were relieved in workhouses. ${ }^{8}$ However, once the economy started to slow down the government initiated policies of austerity in an effort to save public money. These policies included a recommendation that outdoor relief be severely restricted. Poor law inspector Henry Longley delivered a report to the Local Government Board (LGB) - the branch of government responsible for distributing welfare - that recommended outdoor relief be denied to all except the most meritorious cases. ${ }^{9} \mathrm{He}$ recommended that most lone mothers who were previously eligible be denied help. The only exception to this was that widows would be eligible for a period of six months after their husband's death. Within five years of Longley's advice, the number of people being relieved in their homes fell by 276,000 in what became known as the 'crusade against outdoor relief'. ${ }^{10}$ Modern research shows that despite reductions in outdoor relief very few poor law unions adopted all of Longley's advice and, in fact, distribution was very patchy across the country. ${ }^{11}$ 
Although workhouses were never intended to function as children's welfare institutions, they had substantial residential wards for children and schoolrooms where children could be educated. Samantha Shave explains how the Poor Law Commission assumed that between one third and 45 per cent of the workhouse population were under 15 years of age but also felt that children were 'vulnerable and blameless for their poverty'. ${ }^{12}$ The Victorians viewed parental authority as absolute and felt parents were responsible for providing for their children in all circumstances including their own deaths. Such absolutist thought meant that child poverty was inherently understood as a form of defective parenting. For example, one Victorian commentator described the family backgrounds of workhouse children as 'the deserted, the illegitimate, the children of felons, the orphans, and the fatherless'. ${ }^{13}$ Similarly another queried 'where is a poor friendless orphan or foundling (for of these classes the greatest proportion of the workhouse children consist) to turn for assistance when it knows no one on whom it can place confidence or utter complaint? ${ }^{14}$ Such descriptions left no scope for a more nuance discussion about the causes of child poverty, which I argue were largely a consequence of an ineffective system of welfare.

An important consequence of the misplaced assumption that most unaccompanied children under the care of the poor law were parentless was that the assumption continued to be shared well into the twentieth century. Jean Heywood uncritically refers to children in workhouses as 'orphans, bastards and deserted children [or the] illegitimate and motherless, whose parents are convicts, insane or have left the country'. ${ }^{15}$ Similarly, Harry Hendrick asserts that the political significance of workhouse children derived from their parentless status, rather than their destitution, 
because the loss of the parental relationships was the defining feature of these children that allowed them to be 'saved' by the English state. ${ }^{16}$

At the same time that outdoor relief was being severely curtailed, numerous other legislative changes were also being implemented to give the state more control over children. The most important change relevant to this article was that from 1870 school boards were allowed to require children between the ages of five and 13 to attend school for a minimum of five hours a day at a cost to the parent of one penny a week per child. ${ }^{17}$ However, the state did not impose a duty on parents to ensure children attended school until 1876 and a penalty for breach of duty was not introduced until 1880. ${ }^{18}$ The school fees requirement remained in place until $1891,{ }^{19}$ by which time criticisms against poor parents had already led to statutory restrictions on parental rights. Although the government allowed fees to be waived for poor parents, ${ }^{20}$ they also recommended that waivers only be issued in accordance with Longley's severe approach to outdoor relief. ${ }^{21}$ These changes disproportionately affected lone mothers because they could no longer rely on their children for domestic help or petty wages.

Austere policies like Longley's were often justified on the basis that poverty was an inherited condition, and thus, no amount of welfare support would improve matters. ${ }^{22}$ But key child-welfare reformers started to challenge notions of hereditary pauperism by the early 1870 s and argued that children learned habits associated with poverty from their parents, rather than through genetics. ${ }^{23}$ This belief that children learned to be poor, rather than inherited poverty, was an argument that carried considerable weight with lawmakers because it implied children could be converted into better citizens if they were taken away from their families. Child-welfare reformers 
successfully argued that district schools should be used as means to reform poor children into self-sufficient adults who served the state rather than relied on it for support. $^{24}$

Spatial controls quickly became an essential feature of late-nineteenth century child welfare policy. Unaccompanied children under the care of the poor law were to be housed away from workhouses, which were full of adult paupers, in district schools located on the outskirts of London wherever possible. These institutions were vast in size and built to accommodate the substantial number of children from London's poor law unions away from their birth communities, where the children were to be reformed. District schools were the flagship of the poor law school system because they housed hundreds of children, sometimes thousands, and had better resources than workhouse schoolrooms or national schools. Reformers hailed their ability to attract the best teachers because they offered better salaries and higher levels of pupil attainment compared to national schools where non-pauper children were educated. ${ }^{25}$

District schools taught a unique curriculum that combined the traditional subjects of reading, writing and arithmetic with a set number of hours devoted to trade each day. The trade hours were intended to teach the children how to become industrious labourers. Reformers referred to this unique curriculum as 'industrial training' and hoped it would improve the employment prospects of the children by making them economically valuable labourers. ${ }^{26}$ Skilled craftsmen were brought in to teach boys traditional crafts such as shoemaking, tailoring and blacksmithing, while the girls were trained in domestic service skills to prepare them for adult lives as wives or servants. Lawmakers hoped early exposure to skilled labour would give the children a 
hunger for industry that would naturally lead to desirable habits such as truth and obedience, which their parents were perceived to lack.

Children were classified upon entry to the workhouse based on their parental status and sent to the most appropriate public institution. Unaccompanied children constituted the bulk of district school populations because children whose parents were in the workhouse were normally kept on a children's ward in the same workhouse as their parents. A tripartite system of classification was employed from the early 1870 s onward that labelled unaccompanied children as 'orphan', 'deserted' or 'other' to help differentiate parentless children from those with known parents who could potentially exercise their custody rights. ${ }^{27}$

\section{Political discourse and restrictions on parental rights}

'Other' children were of deep concern to Victorian child-welfare reformers because they were perceived to violate spatial controls within district schools and undermine reformation efforts. Key arguments advanced against 'other' children were that they were moral contaminants due to their on-going contact with their parents, ${ }^{28}$ and that their parents repeatedly admitted them for short stays only to be discharged shortly thereafter. ${ }^{29}$ 'Other' children were blamed for introducing bad habits to the rest of the school population who the authorities viewed as redeemable because they were perceived to lack family connections. ${ }^{30}$ Reformers claimed 'other' children routinely moved in and out of district schools because parents saw such provision as means of avoiding their parental duties. ${ }^{31}$ 'Other' children were referred to by derogatory names such as 'ins and outs', 'casuals', 'revolvers', 'the fluctuating class' or the 'foul stream' throughout the Victorian scholarship on district schools. ${ }^{32}$ 
Political discourse directly compared 'other' children to orphan and deserted children as a means of highlighting their dangerous nature. In contrast, the parentless classes were presented as ideal candidates for de-pauperisation because they were not removed from reformation spaces nor did they have contact with biological family members who were viewed as sources of contamination. ${ }^{33}$ The LGB's chief medical inspector, Dr Bridges, presented a report in 1873 that showed the admission and discharge figures for district schools in that year. ${ }^{34}$ The report showed that there had been almost as many discharges as admissions, which Bridges directly attributed to the presence of 'other' children. He explained '[the authorities] were obliged to give them leave $[\ldots]$ they go out, stay for four days ... came back to their little companions, and tell them all about the thefts, tricks, and petty larcenies they had been participators in'. ${ }^{35}$ Bridges concluded 'I am told there is no means of preventing this flagrant scandal and mischief from occurring as often in the year as parents please'. ${ }^{36}$

Following this report, unrestricted custody rights within the poorest classes became increasingly criticised. One reformer explained '[other children] are prone to criminality because of their origins, but the orphan and deserted classes, having no such connexions, are preserved from this source of contamination' ${ }^{37}$ Another reformer reasoned 'the most righteous course seems to be [...] to maintain as closely as possible the balance between parental rights and duties; and when the latter are neglected with injury to the child and harm to the state, for the state to take her defenceless little citizens into her keeping. ${ }^{, 38}$ The statistics from Bridges' 1873 report were referenced in a key government report about the future of poor law schooling as 
evidence of an endemic problem caused by 'other' children. ${ }^{39}$ Lawmakers accepted that there was a link between unrestricted custody rights and population instability in district schools despite the fact there was insufficient information in district school logbooks to support such a claim. Although the authorities usually recorded where children were discharged (including to a parent) Bridges did not use this information to support his claims. Instead, he added a footnote to his report stating 'I believe about a third of this number may be reckoned as leaving for service' ${ }^{40}$

The controversy surrounding unrestricted custody rights reached its climax in the late 1880s and prompted a radical extension of state powers: the Poor Law Act 1889 (PLA 1889). ${ }^{41}$ This statute allowed the poor law authorities to pass a resolution in their favour that transferred all the rights and responsibilities of a parent to the state if a child was 'partly or wholly' maintained by the state. ${ }^{42}$ The legislation established that the maintenance criteria were satisfied if a child was wholly or partly looked after in a workhouse, district school, separate school, infirmary, sick asylum, hospital for infectious diseases or an institute for the deaf, dumb, blind or idiots. ${ }^{43}$ Although an appeals procedure existed, parents could only resume custody of their children if they satisfy a court that their child was not maintained by the state, which was next to impossible if a child was in a district school.

There were 241,116 children chargeable to the poor law in $1889 .{ }^{44}$ The passage of the PLA 1889 meant the state now had scope to intervene in a significant number of previously inviolable family relationships because the children were maintained by public funds. Furthermore, the law created a new and serious risk for parents. If parents abandoned their children to the state, bureaucratic procedures that the parents 
could not control, and perhaps rarely understood, could easily turn a voluntary admission that the parent perceived to be temporary into a permanent arrangement. But even contributing to the upkeep of a child did not guarantee that the authorities would not grant themselves custody. If the authorities passed a resolution, the only option an aggrieved parent who had contributed some form of maintenance had was to fight the resolution in court and prove that his or her child had not been wholly or partly maintained by the state.

Within two years of the PLA 1889 the law was extended further so the state could revoke custody if a parent allowed his or her child to be raised at another person's expense such that a court was satisfied the parent was 'unmindful of their duties'. 45 By 1899 the law was extended to allow the poor law authorities to sever parental rights if a parent was 'unfit' or 'mentally deficient' or 'of vicious habits'. ${ }^{46}$ The appeals process was also tightened to make it more difficult for parents to regain custody of their children after 1899. The new appeals process required parents to satisfy a court that it was for the benefit of the child to be returned to their care in addition to not being maintained by the state.

Reformers hailed the PLA 1889 as a huge step forward for the protection of children. Delegates at the Annual Poor Law Conference in 1889 described the Act as the most 'efficient means for protecting children from ill-usages' and the ideal mechanism for 'holding [parents] to their responsibilities'. ${ }^{47}$ Emotive language was directed at the parents of 'other' children to signal the importance of the new legislation and its ability to curtail the endemic problems caused by 'ins and outs'. The keynote speaker of the conference explained how the law would put an end to 'seeing a child, to all 
appearances an orphan, and for years left under [public] care, unexpectedly claimed, taken possession of by a worthless parent, and thereby condemned to a miserable and far worse than useless life'. ${ }^{4}$

Exploring the empirical backing for the claims that justified the PLA 1889 is important because this statute was the first piece of legislation to allow the state to permanently extinguish parental rights without their consent. The PLA 1889 paved the way for modern child protection legislation but, as the next section will show, it was built on a mixture of misinformation and overstated claims about the agency of poor parents during the late-nineteenth century. It is important to explore these issues because they raise important questions about the legitimacy of original public law interference within the family.

\section{Sources of data}

Questions of parental agency will be tested against data drawn from the logbooks for the 2,423 children who were enrolled in the South Metropolitan School District (SMSD) between 1884-1889. ${ }^{49}$ These records were selected because they cover the years immediately preceding the PLA 1889 and the SMSD was disproportionately criticised for a problem with 'other' children. ${ }^{50}$ The SMSD was also the largest school district in England at that time. ${ }^{51}$ It was formed in 1849 to accommodate children from some of the most deprived and densely populated poor law unions in London including St Olave, St Mary Magdalen, Bermondsey, Rotherhithe, St Giles, Camberwell, Greenwich, Newington, Woolwich and Stepney. The district operated between 1851-1902 and managed Brighton Road School in Sutton Surrey, which was the largest district school within the poor law framework with over 1,500 beds. ${ }^{52}$ 
Other sites within the remit of the SMSD included Banstead Road School in Sutton, Witham School in Essex and Herne Bay Convalescence Home in Kent.

Some children in SMSD schools were transferred from London workhouses whereas others were admitted directly by parents who were unable, or unwilling, to care for them. When a child arrived at a district school admission officials recorded a very limited amount of information. The logbooks have columns for a child's name, birth year, sex, classification, admission/discharge date, next of kin name/address along with a 'remarks' section that recorded details of where children were sent upon release. On a practical level, institutional sources like these reflect the context and purpose for which they were used. The poor law authorities had tens of thousands of children in their care during the late-nineteenth century and it would have been impossible to capture detailed information about every child. Nonetheless, these records provide the only evidence of what the authorities actually knew about the children in their care, and there is a notable lack of information about why children with known parents were being looked after by the state.

\section{The risk of parents abusing custody rights}

The poor law authorities classified children and captured next-of-kin information when they entered the SMSD. A detailed reading of the logbooks from 1884-89 suggests at first glance that the anxieties expressed by reformers about potential abuses of custody rights were not overstated because the majority of the population was classified as 'other' (figure 1$)^{53}$. Only 28 per cent of SMSD admissions were orphan or deserted children, whereas 68 per cent were classed as 'other' and therefore liable to being removed by a parent. Four per cent were unclassified and thus an 
unknown risk. The 'other' class consisted of 1,642 children and 96 per cent of them had parents listed as their next of kin (figure 2). ${ }^{54}$ Sixty-four per cent of 'other' children had parents with residential addresses known to the authorities, but only nine per cent of them were fathers. Mothers with residential addresses were the most common next of kin whereas fathers with residential addresses were the least (figure $3) .55$

This shows how misleading was the assumption that poor law schools were full of parentless children and illustrates some of the complexity surrounding the nature of childhood poverty during the late-nineteenth century. This misconception obscured the reasons why children were voluntarily admitted to the care of the state during this period and the relationship those reasons bore to the erosion of parental rights in England. Large numbers of mothers were prepared to give up their children to the poor law authorities but refused to sever contact with them, which suggests there were significant numbers of mothers who needed assistance but were unprepared to enter the workhouse themselves. Most of these women were viewed as deserving prior to Longley's proposals because they were dealing with hardships such as spousal separation/death, housing crises or the burden of large numbers of children at the time they admitted their children into care. ${ }^{56}$

The new austere system treated these women the same as the irredeemable and forced them to choose between entering the workhouse and receiving nothing. I argue that the disproportionate number of 'other' children in the SMSD was most likely an unintended consequence of welfare reduction. The substantial presence of 'other' children suggests struggling parents may have consciously institutionalised their 
children, but refused to permanently desert them, because institutionalising children allowed parents to escape the workhouse whilst navigating the new compulsory education system. The SMSD logbooks provide a corrective view of the types of people who sought relief in Victorian England. 'Other' children far outnumbered orphans and deserted children because, quite simply, there were considerably more children with on-going parental relationships in need of relief during the latenineteenth century than parentless children.

Before 1889, the dominant presence of 'other' children raised the prospect of parent's abusing their rights because parents had unrestricted rights of custody. This, coupled with the empirical evidence supplied by Dr Bridges, helps explain how political discourses surrounding 'other' children led to legislative change. However, the SMSD logbooks show that those premises were highly simplistic and did not accurately reflect the actual situation. Extending the examination of next of kin to the deserted and orphan classes reveals that a number of deserted children were also capable of being reclaimed by a parent, and that even orphaned children had enduring family connections (figures 4 and 6). ${ }^{57}$

There were 260 children from the sample classified as deserted, almost half of whom had named parents listed in their records. Far fewer deserted children had extended relatives and almost a quarter had no next of kin. However, a child could have two living parents and still be classed as deserted if one of them deserted the family and the other was incapacitated, incarcerated or abroad. ${ }^{58}$ Eighteen per cent of deserted children had named parents with known addresses, and 24 per cent had named parents without addresses (figure 5). ${ }^{59}$ Only seven per cent had parents in the workhouse, 
whereas the remainder had other relatives listed as their next of kin. There were 48 children classed as deserted despite having a parent outside a public institution and thus were not classified in accordance with the law. Most were mothers with residential addresses, but a few were fathers with warrants against them for financial contributions. It appears there was a lack of alignment between the law's definition of desertion and its practical application. Because the authorities classified children as deserted who had parents capable of claiming them, their behaviour raises doubts about the number of truly deserted children in district schools and leaves an element of confusion surrounding the process of classification based on parental circumstances.

Of the 408 children from the sample classed as orphans, most had biological relatives recorded and were therefore not as devoid of family ties as Victorian rescue narratives implied (figure 6). ${ }^{60}$ The most common next-of kin-relationships for this group were aunts, uncles, siblings and grandparents, but sometimes non-biological kin or associates such as stepparents or friends also made themselves known to the authorities. Only 22 per cent had no registered next of kin, which challenges the dominant narrative of 'friendlessness' advanced by child rescuers. Four per cent had named parents and thus did not comply with the LGB's definition of desertion. ${ }^{61} \mathrm{~A}$ small number listed mothers living outside the workhouse as next of kin (figure 7). ${ }^{62}$ Ten orphans had mothers with residential addresses in the parish of Camberwell but it is unclear why they were classified this way. Further investigation into their circumstances provided no answers. For example, William and Jabez Elliot were originally labelled as 'other' children when they were admitted to the workhouse with their mother in the early $80 \mathrm{~s} .{ }^{63}$ However, when the authorities transferred them to 
Brighton Road School a few years later they were reclassified as orphans. This reclassification implied their mother died, however, the boys were later transferred to Witham School with their mother listed in their records with an address in Newington. ${ }^{64}$

It is clear that the tripartite system of classification could not measure the investment of parents in their children. Its inherent simplicity made it easy to dismiss 'other' children as carelessly parented and 'deserted' children as abandoned, thereby providing a justification for the presence of the state in the lives of children such as Henry and Fredrick Belville. The Belville brothers were the oldest two children of Emma and George who moved to the parish of Camberwell from their original home in Brighton in 1873. George disappeared from the family home in the late 1870s, which forced Emma to seek work as a clothes-ironer to support her four children. ${ }^{65}$ After three years of self-support, Frederick and Henry were admitted to the Camberwell authorities at the ages of ten and twelve. They were immediately dispatched to Brighton Road School where they were classified as deserted with no next of kin. ${ }^{66}$

The initial evidence from the SMSD logbooks suggests both George and Emma permanently abandoned their sons because they were labelled as deserted. This implied the authorities had no reason to fear they were at risk of parental reclamation. However, within a year of being admitted to Brighton Road School, George reappeared and reclaimed Frederick and Henry to his care. ${ }^{67}$ There is no evidence George became reunited with Emma during this period, but within six months he readmitted his sons to Brighton Road School and the authorities re-classified them as 
'other' children with George as their next of kin without an address. ${ }^{68}$ The children remained at school until they were 14 and 16 when the poor law authorities arranged for them to be sent to the Exmouth training ship. By the following census the boys were reunited with their mother. ${ }^{69}$

The Belville case history illustrates how the Victorian classification system was unable to administer complex issues surrounding child poverty because it oversimplified family circumstances. Despite the limited information from the available sources, inferences can be drawn that Emma was forced to institutionalise her sons after the breakdown of her relationship, but had no intention of deserting them permanently, as evidenced by their reunion in adulthood. There is no evidence of contact between them throughout their time at Brighton Road School, but their eventual reunion confirms family bonds remained intact despite lengthy separation. Emma's decision to admit her school-aged children whilst keeping her infants at home had sound reasoning. Infants were sent to workhouses, because they were too young for district schools, where conditions were often perilous. Also, Emma would also have remained liable for school fees for her sons, yet not been eligible for outdoor relief due to the harsh reductions in social welfare. By presenting her sons as deserted, she was able to keep herself and her infant daughters out of the workhouse and ensure her school-aged sons were educated as required by the law.

\section{The reality of parental use of custody rights}

Reformers argued 'other' children were the root cause of population instability in district schools because parents abused their custody rights to avoid their responsibilities. ${ }^{70}$ Dr Bridges 1873 report was cited in the LGB's annual report in 
1889 as evidence that parents were abusing their custody rights. ${ }^{71}$ Four years after the PLA 1889 was passed Dr Bridges told the LGB that 'the population is now in the highest degree of fluctuation' ${ }^{72}$ Reformers and members of parliament alike referenced his findings without critique as proof that 'other' children were a serious problem and the law was quickly extended to reduce parental rights further. ${ }^{73}$

The evidence drawn from the SMSD logbooks suggests Dr Bridges' conclusions were inaccurate. His figures do not show rates of parental reclamation. Instead Bridges' figures show that there was a profound lack of investigation into where children from district schools went after they were discharged. A close reading of the SMDS logbooks clearly shows that the reality was far different from Bridges' assumptions (figure 8$).{ }^{74}$ Children were more likely to be transferred internally within the poor law framework to places such as other poor law schools or training ships (36 per cent) than discharged to parents or family (16 per cent). Ten per cent went into service or apprenticeship and another 30 per cent were not discharged at all over the five-year period. Bridges' reports led to the distribution of misleading content at policy level, and ultimately contributed to the passage of the PLA 1889, and that is why this inquiry is relevant. By not publishing details about where the children were discharged, accusations of parents abusing their custody rights were overstated and misrepresented.

Institutional sources reflect the administrative reality at the time, which was heavily over burdened. In 1871 the LGB reported that there were 39,542 chargeable children in poor law schools, but that only 4,705 were accommodated in district schools because most unions could not afford to build vast children's institutions. ${ }^{75}$ 
Administering thousands of children with limited resources invariably ran the risk of errors being made or information not being properly recorded. It is entirely possible some of the children that were not discharged, or that were sent to unknown locations, were in fact administrative errors and had been collected by parents. However, the records do confirm that 46 per cent of the sample was discharged by poor law administrators to locations within the system, or work situations, rather than family homes.

This casts an entirely different light on the severity of the problem caused by parental agency within district schools. If district schools were in fact unstable, poor law administrators played a larger role than the parents. However, South Metropolitan schools were criticised more severely than other institutions for their inability to stabilise their populations as evidenced by Dr Bridges' second report. In the 1880s, the blame for this perceived instability fell squarely on the parents. The findings from this survey show allocating blame to parents was unfair because a significant degree of instability was the result of internal administration rather than parental action. ${ }^{76}$ Much like the misconceptions about the family backgrounds of juvenile paupers, it could be that many commentators were aware of this administrative turnover, but disregarded it as a necessity and shamed parents without explaining that they were a very small part of the problem.

Another key argument advanced by reformers in the 'ins and outs' discourse was that parents repeatedly readmitted their children for short periods - thus continually contaminating reformation spaces. ${ }^{77}$ Yet again, this assertion appears to be significantly overstated. Drawing on the SMSD records between 1884-89 only 343 
children of 2,423 admitted during that period were discharged to parents. ${ }^{78}$ Ninetytwo per cent of those parental discharges were 'other' children, yet there is very little evidence to support reformers' claims about casual readmission. All the children who were discharged to a parent were traced through the SMSD logbooks between 188292 to look for evidence of readmission before and after the period of observation. This investigation revealed 89 per cent were admitted once and only 11 per cent twice or more (figure 9). ${ }^{79}$ Again, it is entirely plausible some parental discharges were unreported, or the problem manifested itself in a way that sometimes escaped central administration. However, when this information is contextualised within the patterns of ambiguity generated by administrators like Dr Bridges it has to be considered that claims of routine readmission were also exaggerated.

Following these findings, the label 'other' should really be understood as a term applied to children whose parents used public childcare as a coping mechanism, rather than an escape from their responsibilities. The combined pressures of welfare reduction and mandatory school fees placed such tremendous burdens on impoverished families that the lived experiences of the poor were exceptionally unstable in late-Victorian London. It appears the term 'other' really denoted a level of cooperation with the Poor Law authorities and an expectation that the children would be collected once the family situation had stabilised. Murdoch argues that a similar situation occurred in the philanthropic sector, where poor parents viewed admissions procedures as a process of negotiation to help them secure better training options for their children than they could offer. ${ }^{80}$ 
The result was a gap in expectations because the poor had their own ideas about how welfare services should operate that differed from the goals of providers. In a period of severe austerity, poor parents had very few options as to how to navigate their misfortunes. Child-welfare reformers perceived the choice to send a child to public childcare, as well as the choice to reclaim a child, as serious abuses of parental rights and on this basis repeatedly called for legislative action to enhance state intervention in the private sphere. The complex case history of Sarah Ann Carlo provides an illustration of how Victorian commentators were unable to articulate why parents chose to institutionalise their children because commentators misunderstood the nature of childhood poverty during the late-nineteenth century.

Sarah Ann was one of five children born to John and Elizabeth Carlo in Camberwell during the 1870s. John was a bricklayer and the family lived on Crown Street, which Charles Booth classified in 1889 as inhabited by the "vicious and semi-criminal classes' ${ }^{81}$ In 1880, John was admitted to Caterham Imbeciles Asylum, which left Elizabeth as sole parent to care for their four school-aged children, Emma, Arthur, William and Sarah Ann, along with their infant daughter Beatrice. Immediately after John was admitted to the asylum Elizabeth sent Emma to her sister-in-law in Essex and entered Gordon Road workhouse with her remaining children. ${ }^{82}$ She discharged herself within a matter of months and took Beatrice with her. She left the three school-aged children behind with the agreement of the authorities.

William was transferred to the infirmary for a period due to illness, which delayed his entry to Brighton Road School until the following year. For unknown reasons Arthur was moved back and forth between Gordon Road and Havil Street workhouses for 
over a year, whereas Sarah Ann was transferred to Brighton Road within two weeks of being admitted by the Poor Law authorities. ${ }^{83}$ All three children were classified as 'other' upon entry with Elizabeth's name and address in their records as their next of kin. After leaving the workhouse, Elizabeth and Beatrice returned to Crown Street as lodgers in the Austin household, and Elizabeth worked as a charwoman to support them. ${ }^{84}$ In 1886, Elizabeth married a local engineer who had three sons and whose wife had recently died. ${ }^{85}$ The same year the authorities discharged Elizabeth's two sons and sent William to an army band and Arthur to the army as an infantry soldier. ${ }^{86}$ Two years after her marriage, Elizabeth removed Sarah Ann from Brighton Road. They were still living together at the time of the following census, and there is no evidence that either of them returned to the workhouse in their lifetimes. ${ }^{87}$

The triggers for public law intervention into the lives of the Carlo children stemmed from parental misfortune rather than immoral habits or parental neglect. Elizabeth sought custody of Sarah Ann as soon as her circumstances stabilised and managed to avoid admitting Emma or Beatrice to public childcare through the help of extended family and strategic decision-making for her school-aged children. She relied on the workhouse in the immediate aftermath of her husband being institutionalised, which left her without a wage earner and the burden of three pence school fees per week. Her case history shows how the complexity of child poverty simply could not fit within the narrow constructs of acceptable dependency and highlights how inappropriate the policies behind early child protection measures were in terms of helping vulnerable families. 
The final argument advanced by reformers against the parents of 'other' children was that they caused administrative disruption due to the short duration of their stays. ${ }^{88}$ Measuring the time between the admission and discharge dates for the 343 parental discharges from this sample suggests this claim had merit because most children stayed in the SMSD less than two years (figure 10) ${ }^{89}$ Forty per cent stayed for less than one year and a further 20 per cent stayed less than two years, whereas only 29 per cent of cases stayed for prolonged periods, such as Sarah Ann Carlo who spent more of her childhood in public childcare than parental care.

Assertions of dramatic population instability were overstated, but claims that 'other' children were prone to shorter stays appear accurate. Victorian commentators did not acknowledge the broader reasons behind childhood institutionalisation during the latenineteenth century. Streamlining complex social issues about the causes of child poverty into simplified notions of 'deserving' and 'undeserving' distorted even those whose experiences as parents did fit the descriptions of 'ins and outs.' George Beilby Senior and Catherine Beilby had eight children between the late-1870s and early-90s named Caroline, Catherine, George Junior, Maud, Ethel, Elsie, Florence and Beatrice. The instability of their family's circumstances first became apparent when Caroline was sent to Brighton Road School after George Senior entered Havil Street workhouse. Caroline was the only school-aged child in the family at the time. ${ }^{90}$ Within three weeks of arriving, George Senior discharged himself and reclaimed Caroline from the authorities. Two years later, he was readmitted to Havil Street and brought his school-aged children Caroline, Catherine and George with him. The children were sent to Brighton Road School. Three months later George Senior 
discharged himself again, but this time only reclaimed his son, leaving Caroline and Catherine for another month before resuming custody of them. ${ }^{91}$

Two years passed before George Senior was readmitted to the workhouse, but he only brought Catherine and George Junior who returned to Brighton Road School for an unknown period. ${ }^{92}$ The logbooks show both children were readmitted 18 months later just as their mother bore twin daughters Florence and Beatrice. ${ }^{93}$ The family remained free of public assistance for two years, but unfortunately, George Senior returned to the workhouse on New Years Day 1889 and took George Junior, Caroline, Beatrice and Catherine with him. ${ }^{94}$ Over the coming years, Catherine Senior bore three more daughters named Ethel, Maud and Elise, and the Beilby school-aged children continued to fluctuate in and out of district schools throughout the early 90s. In total, three of George's children had five admissions and three others had three admissions. Only Maud and Elsie escaped public childcare entirely. ${ }^{95}$

George Beilby conformed to the negative descriptions of 'ins and outs' because he was exactly the type of parent that reformers wanted to see denied public assistance. Although his behaviour might have caused administrative disruption, the extent to which it impacted upon the physical and moral retraining of the entire school population is unknown. The instability discourse made no allowance for the broader causes of poverty because the root causes of childhood poverty conflicted with contemporary values and moral ideals. Arguably, George Beilby was a casual pauper, but he also proactively used the district school system to help navigate the difficulties posed by a large number of children and the burden of unmanageable school fees. He had other hardships, too, including his inability to maintain a consistent occupation -- 
in 1875, George Senior described himself as a painter on Caroline's baptismal certificate but described himself as a coachman in the 1881-91 censuses and a furniture porter in $1901 .^{96}$

The family also experienced significant housing difficulties as they expanded. In 1881 they lived on Frankton Street, but in 1888 George sent Catherine and Caroline to Sumner Road School in Peckham, a national school, and listed Bournemouth Road as the new address. ${ }^{97}$ This was one of six national-school admission records that show George Senior tried to educate his children at national schools as required by law when he was able. There were no records to verify how long they stayed at Sumner Road, but 14 months later the girls were returned to Brighton Road School because their father had returned to the workhouse. In early 1890, George Senior sent his son to a national school in Southwark and told admission officials the family lived on nearby Imperial Buildings Road. ${ }^{98}$ Again, there was no discharge record for George Junior, but he was admitted to Brighton Road School in December 1890, making Comber Grove his only education outside the Poor Law system before the authorities sent him to Exmouth in $1893 .{ }^{99}$ In 1892 , George registered Beatrice and Ethel at a national school in Southwark and told admission officials the family lived on Meeting House Lane. However, by the time he admitted Florence to the same national school later that year the family had moved again to Fenham Road in Southwark. ${ }^{100}$ The family moved two more times before they settled in Croydon in 1901 with their youngest daughters. ${ }^{101}$

By looking at the wider sources of evidence surrounding the Beilby family, some of the misrepresentations from the instability discourse begin to emerge. Although 
George Senior had a casual relationship with the workhouse that forced his children to have casual relationships with district schools, he also was successful in keeping his wife and infant children out of the workhouse and provided national education at his own expense where possible. Nuanced depictions of the lived experiences of the poor such as this are absent from the Victorian sources and allow prominent causes of poverty such as spousal death/institutionalisation, unemployment or housing crises to be removed from the discussion about the disproportionate presence of 'other' children in district schools.

\section{Concluding remarks}

The SMSD logbooks reveal important information about the interactions between parents, children and the Poor Law authorities that the 'ins and outs' discourse sought to minimise and popular narratives either oversimplified or misrepresented. The same institutions that generated the parentless myth also produced evidence of a very different administrative reality. Most of the children from the sample had on-going relationships with at least one parent (usually their mother) and were more likely to be discharged by virtue of public law action than parental agency.

Although school populations had the potential to be widely disrupted by unrestricted parental rights before 1889 , there are reasons to believe these fears were overstated. Most parents consciously institutionalised their children to ease the burdens posed by other changes in the law. Nonetheless, these fears did play a role in developing public sentiment in support of the successful campaign led by middle-class reformers to introduce the first restrictions on parental rights in England during this period. If it were not for the substantial presence of 'other' children in district schools it is 
debatable whether the powers created by the PLA 1889 would have been initiated when they were because there was little justification for public interference over truly parentless children. By presenting previously worthy welfare recipients -- such as lone mothers -- as threats to their children, and indirectly to parentless children, lawmakers were able to defend the erosion of parental rights on the basis that the adult citizenship of protected children was at stake when in fact the state was trying to protect itself from future expenditure. 


\section{Figures}

Figure 1. Classification of the SMSD population 1884-89

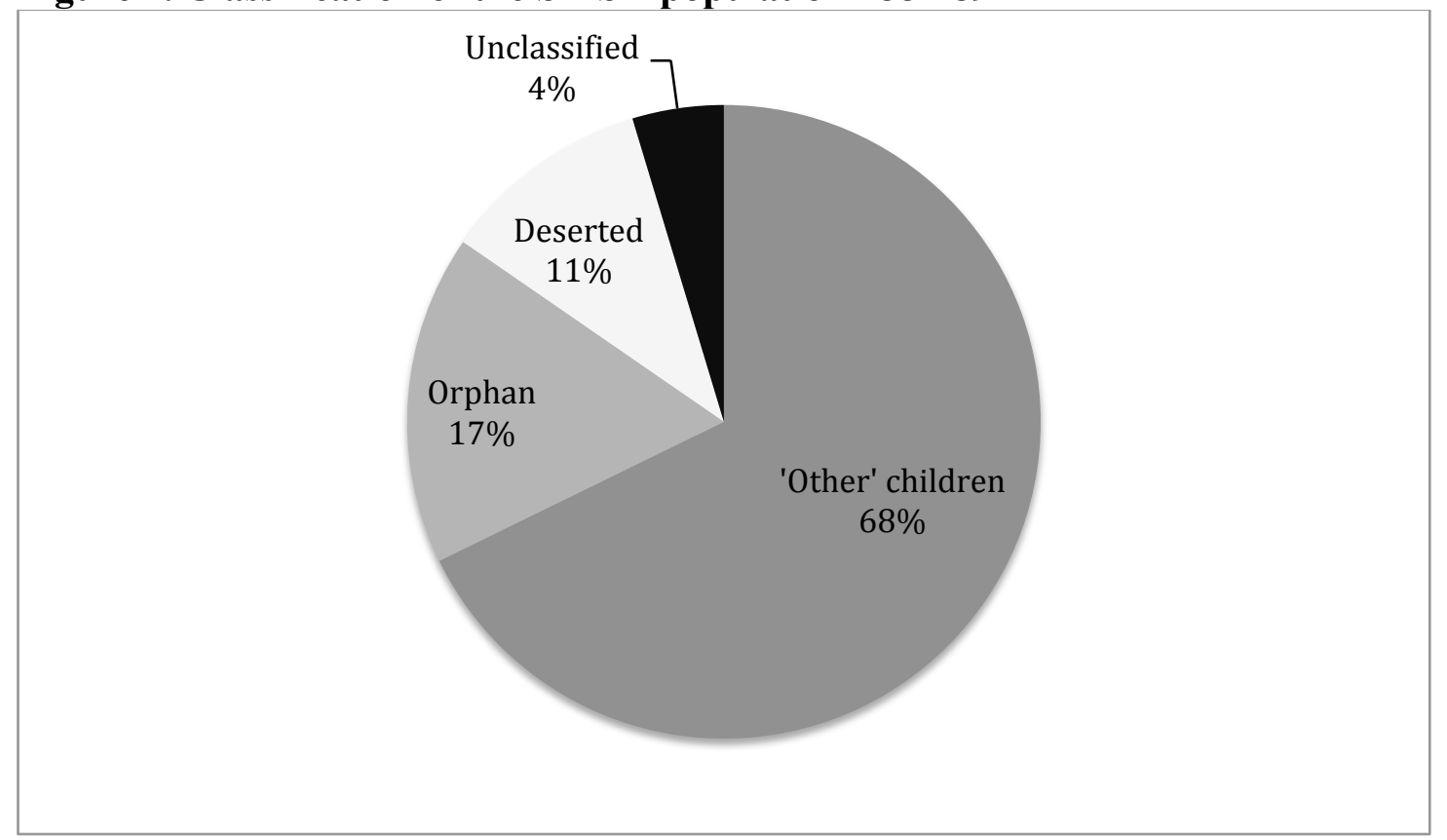

Figure 2. Next of kin relationships for 'other' children 1884-89

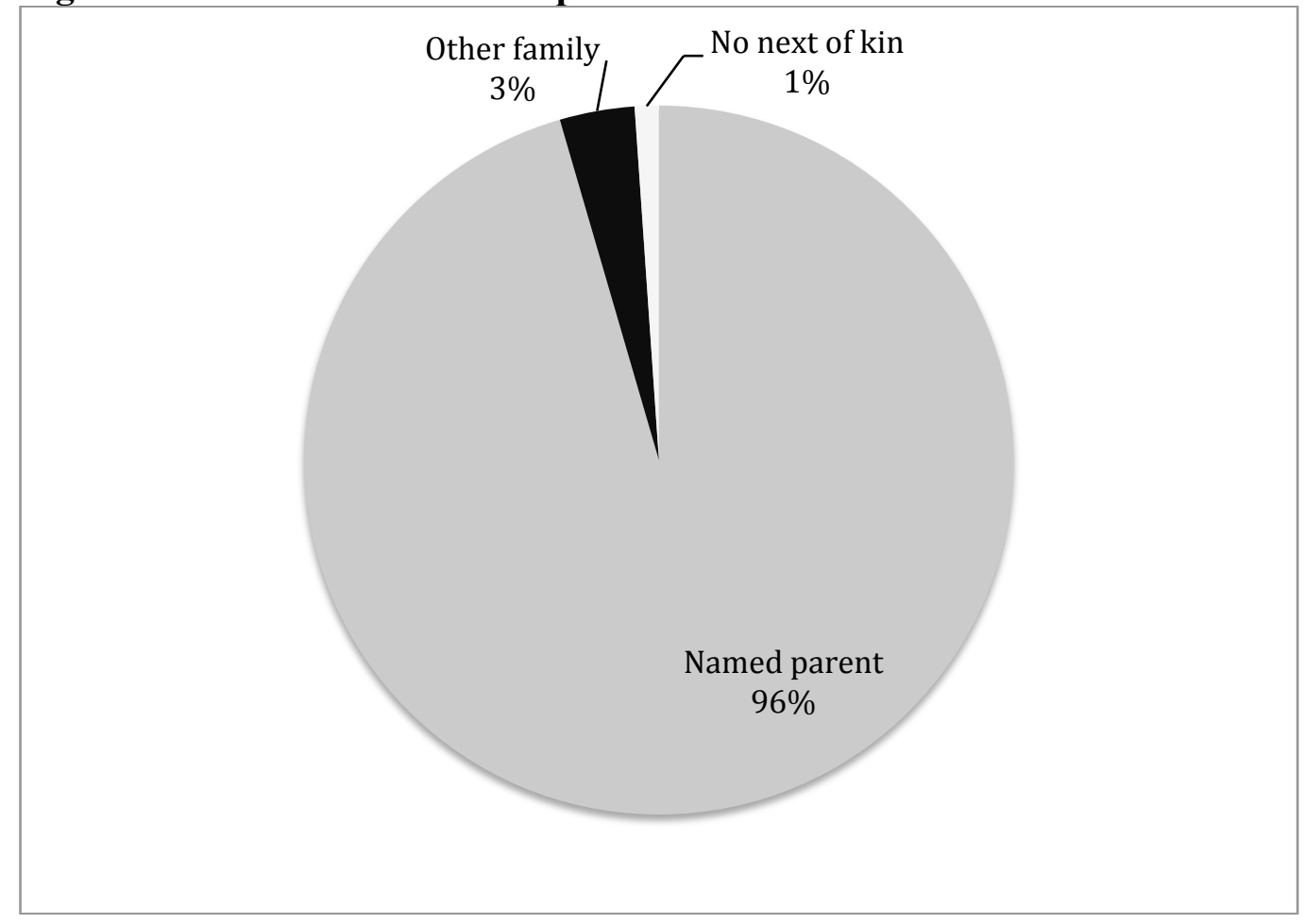


Figure 3. Residential addresses for 'other' children's next of kin 1884-89

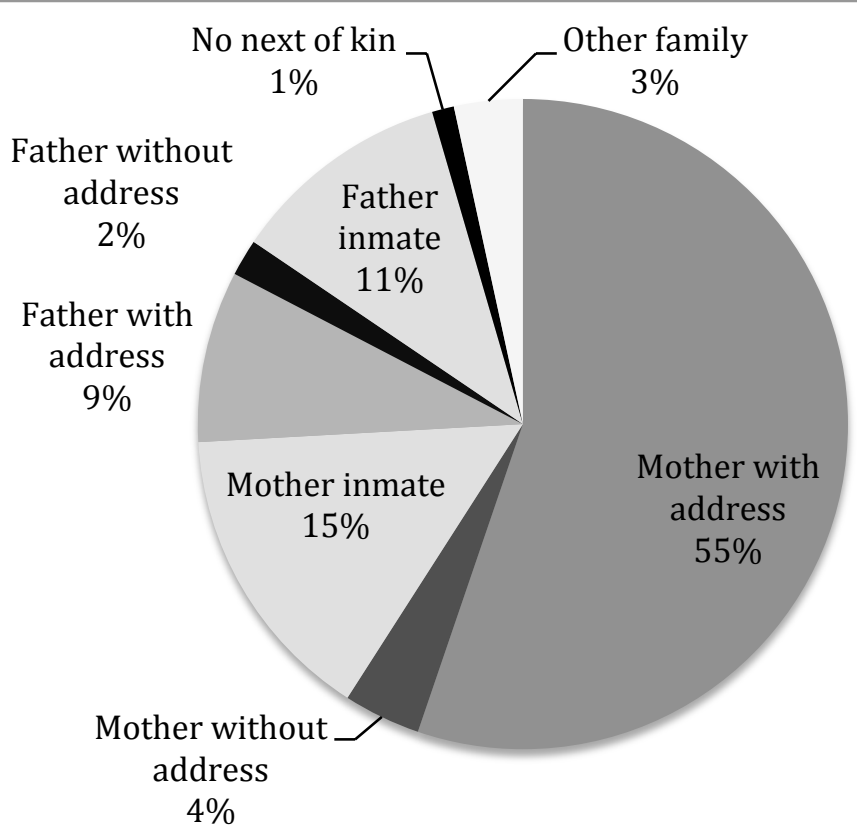

Figure 4. Next of kin relationships for deserted children 1884-89

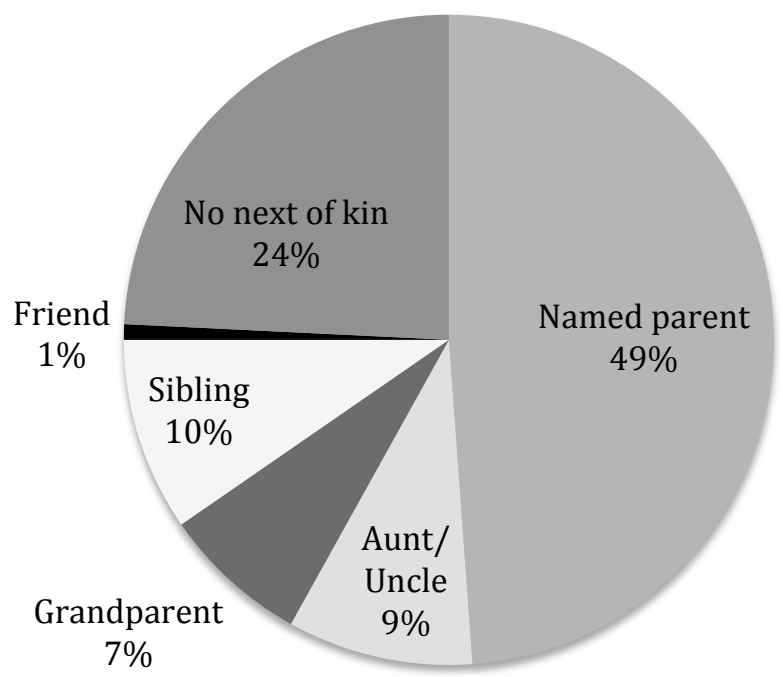

Figure 5. Residential addresses for deserted children's next of kin 1884-89 


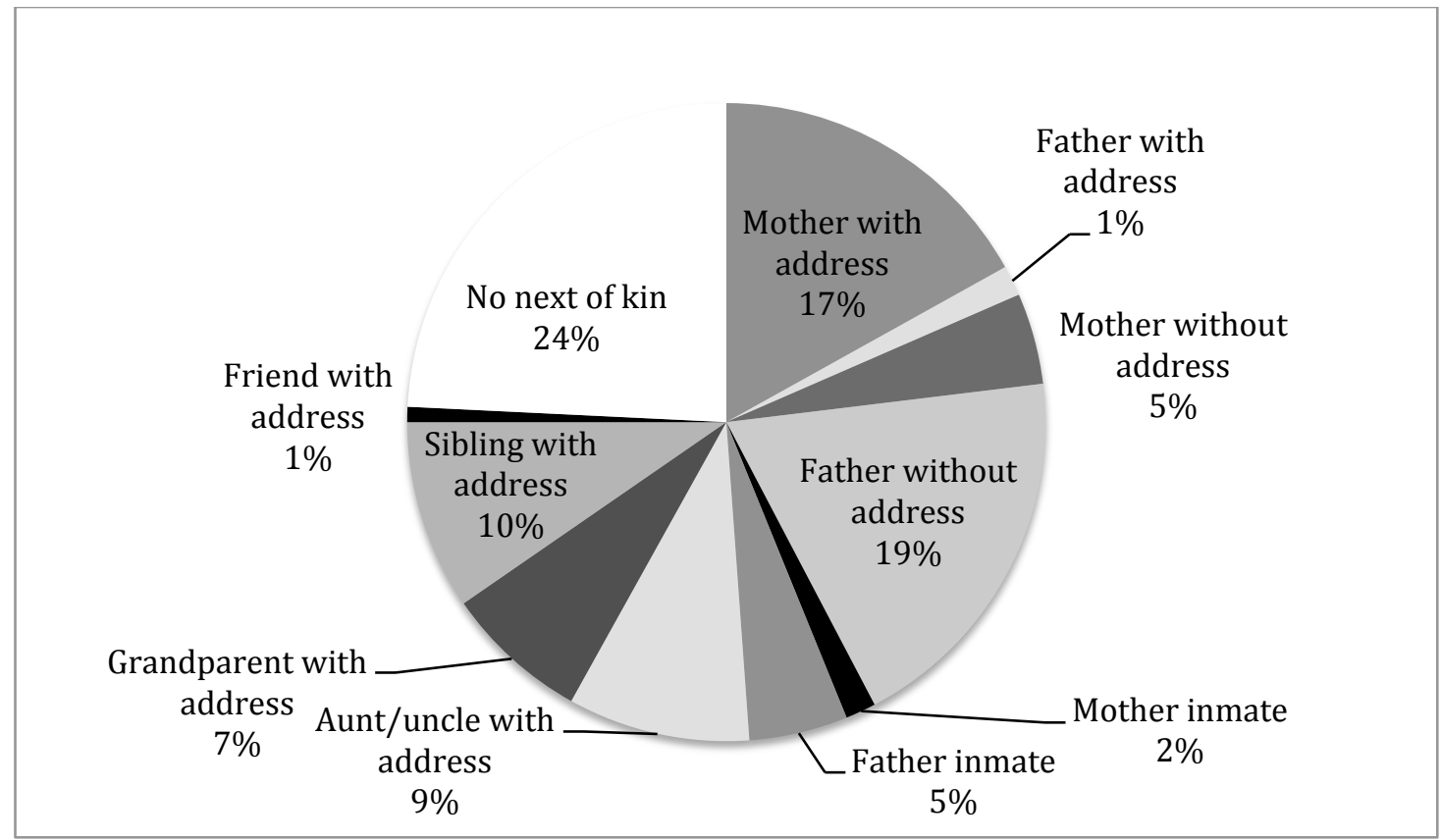

Figure 6. Next of kin relationships for orphan children 1884-89

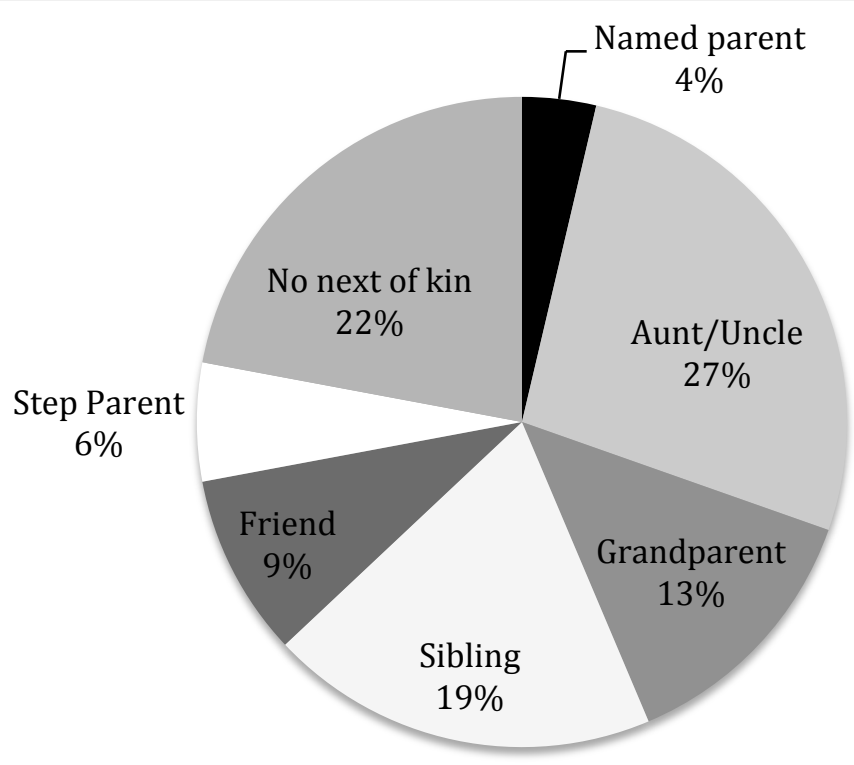

Figure 7. Residential addresses for orphan children's next of kin 1884-89 


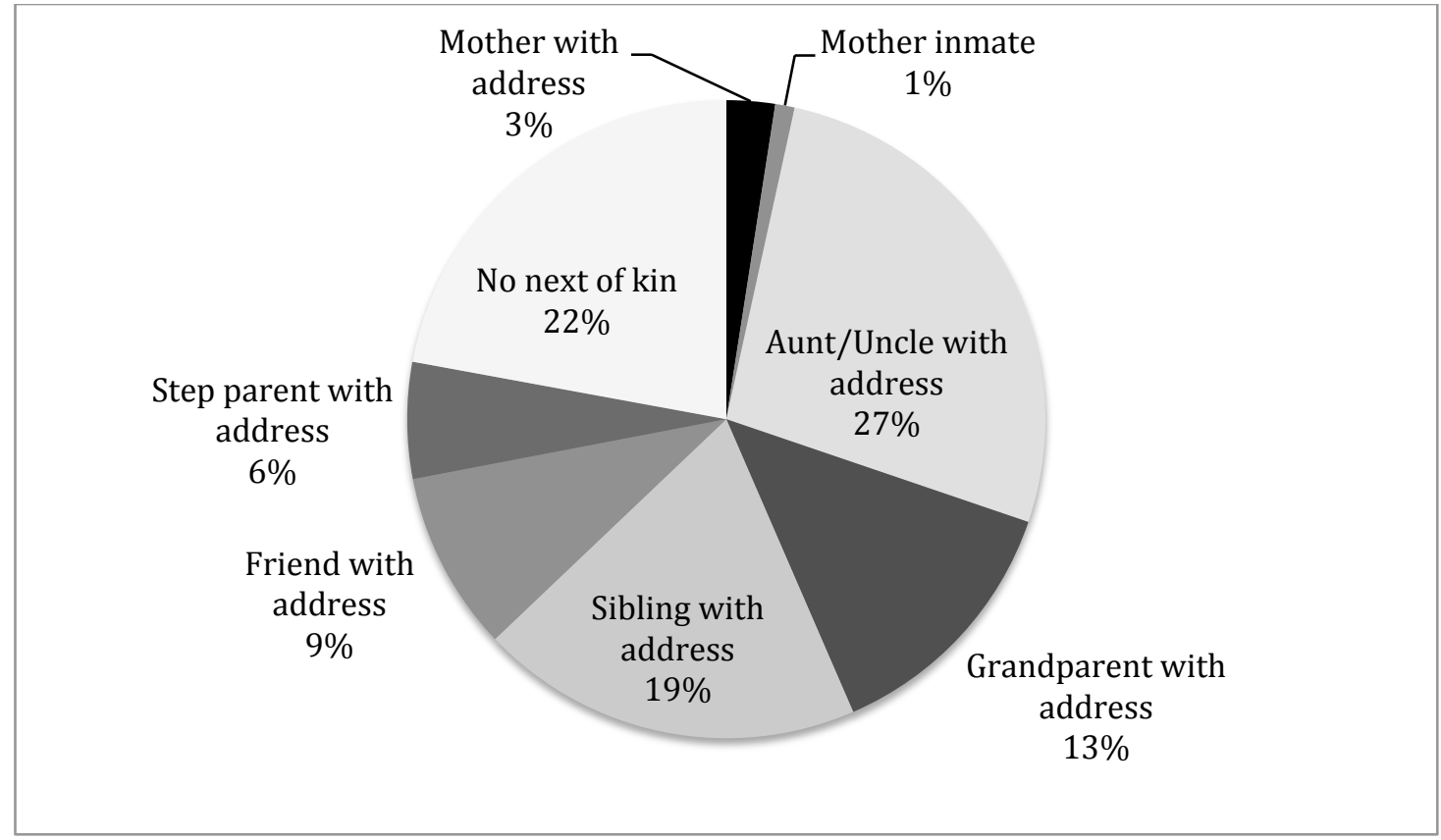

Figure 8. Discharge destinations all classifications 1884-89

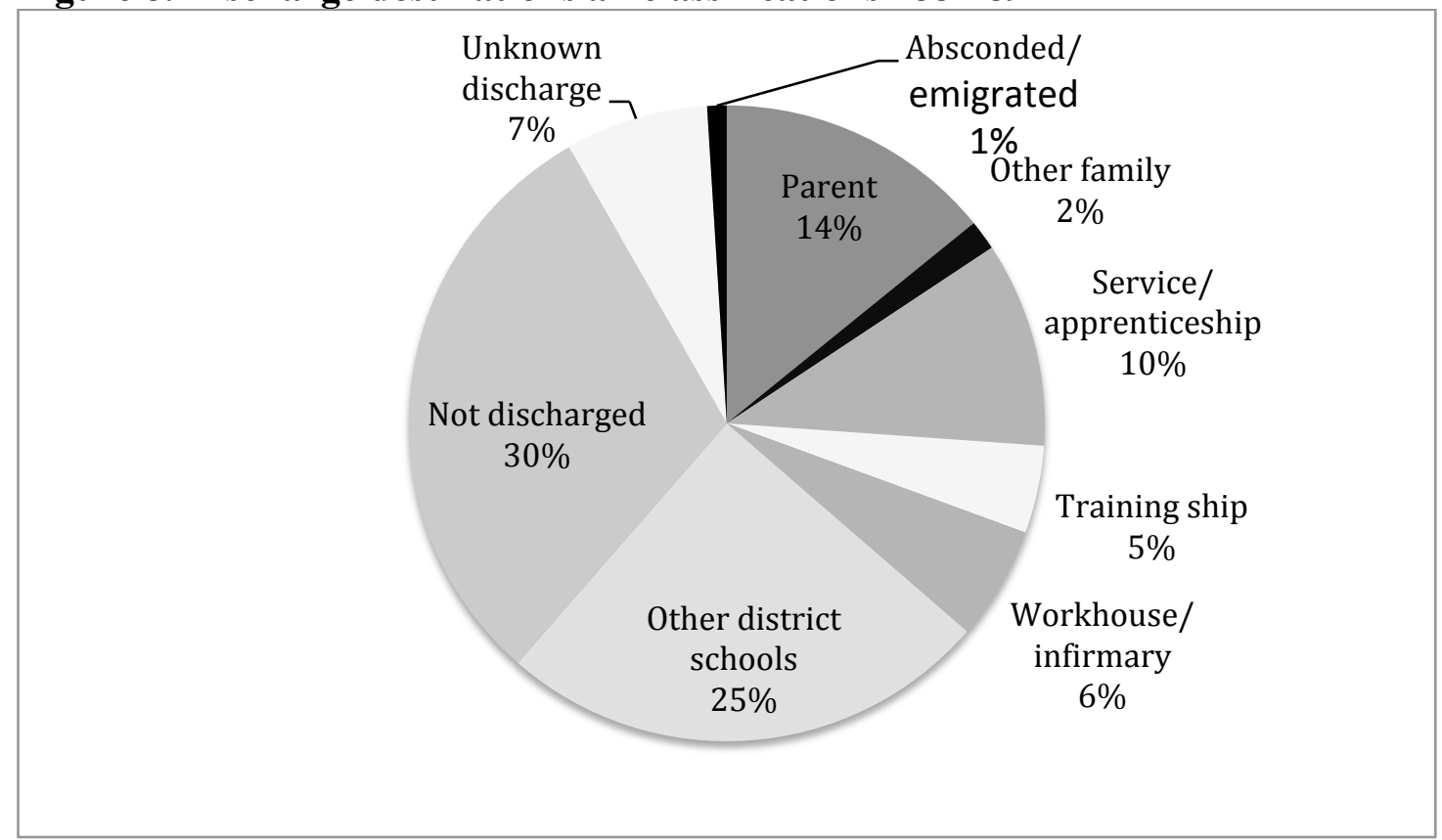


Figure 9. Discharges and re-admissions by parents 1882-92

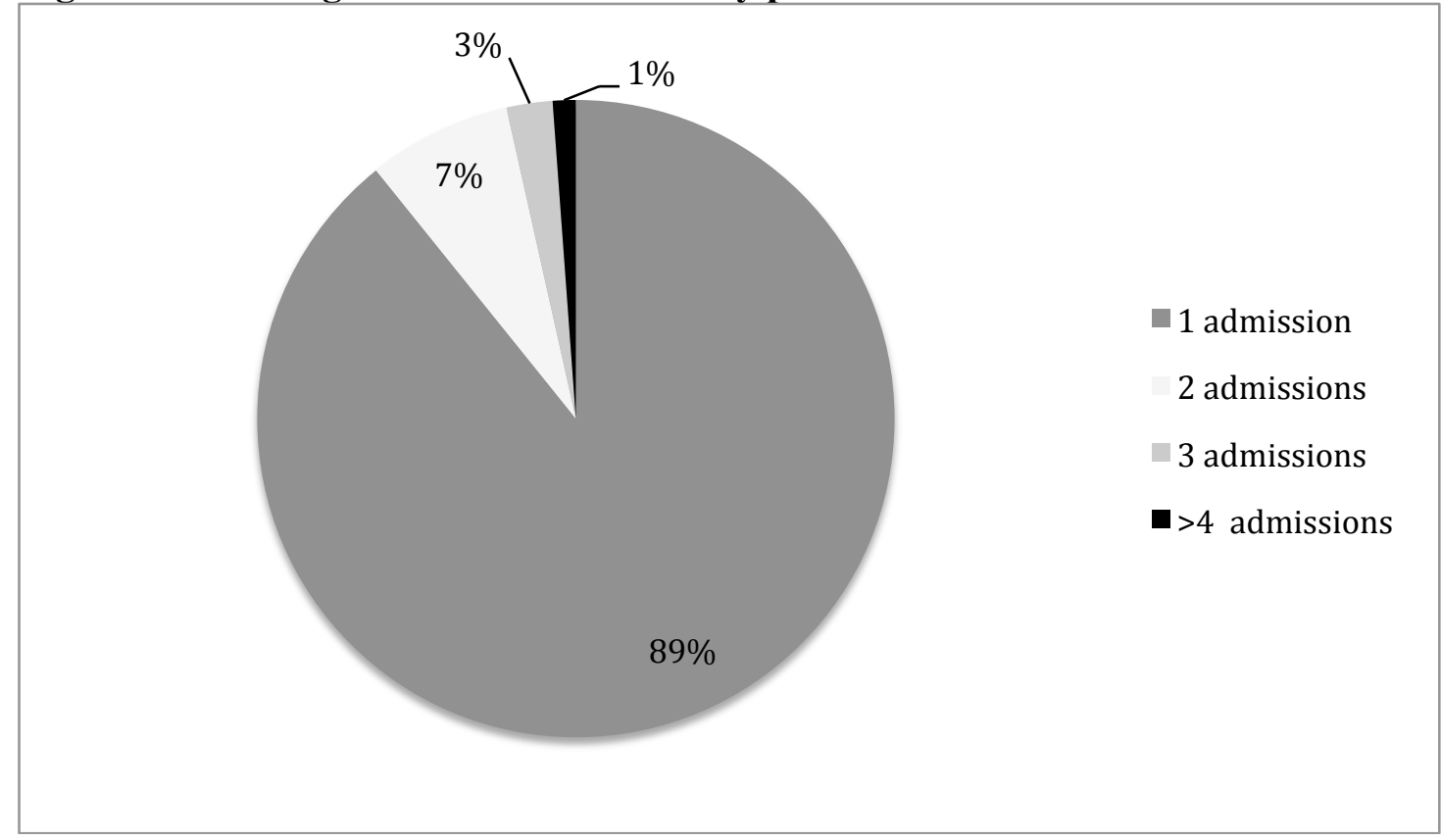

Figure 10. Admission durations for children discharged by a parent 1882-92

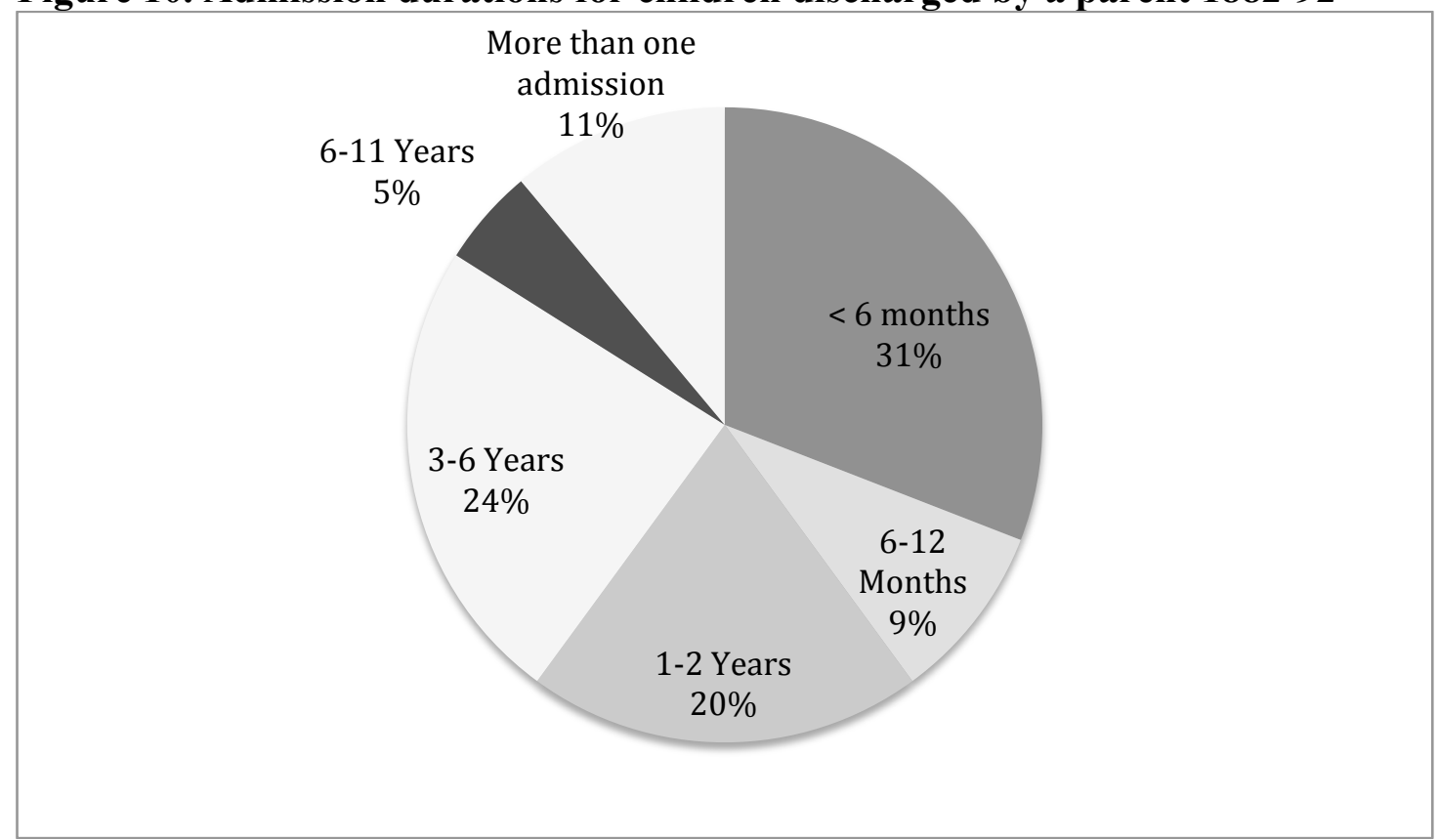




\section{Endnotes}

${ }^{1}$ See Shurlee Swain, 'Child Rescue: The Emigration of an Idea' in Jon Lawrence and Pat Starkey (eds), Child Welfare and Social Action in the Nineteenth and Twentieth Centuries (Liverpool University Press 2001) and Lydia Murdoch, Imagined Orphans: Poor Families, Child Welfare, and Contested Citizenship in London 1870-1914 (Rutgers University Press 2006).

${ }^{2}$ Rachel Pimm-Smith, 'Juvenile de-pauperisation: The journey from public childcare to English citizenship 1884-1900' (DPhil thesis, University of Warwick 2019).

${ }^{3}$ Pimm-Smith, 'Juvenile de-pauperisation' Pages 108-160.

${ }^{4}$ Pat Thane, Old age in English history: past experiences, present issues (Oxford 2000) Pages 270-272.

${ }^{5}$ Nigel Goose, 'Poverty, old age and gender in nineteenth-century England: the case of Hertfordshire' (2005) 20 Continuity and Change 351.

${ }^{6}$ Royal Commission, Inquiry into the Administration and Practical Operation of the Poor Laws 1834 (C ( $1^{\text {st }}$ Series)) Page 127.

${ }^{7}$ Joseph Harley, 'Material lives of the poor and their strategic use of the workhouse during the final decades of the English old poor law' (2015) 30 Continuity and Change 71.

${ }^{8}$ Karel Williams, From Pauperism to Poverty (Routledge 1981) Page 102;

${ }^{9}$ The Local Government Board: Third Annual Report 1873-74 (C ( $2^{\text {nd }}$ series)) Pages 204-205.

${ }^{10}$ Williams, From Pauperism to Poverty Page 102; Kim Price, 'The crusade against out-relief: a nudge from history' (2011) 377 The Lancet 988.

${ }^{11}$ Elizabeth Hurren, "'World Without Welfare": Pauper Perspectives on Medical Care Under the LateVictorian Poor Law 1879-1900' in Obligations, entitlement and dispute under the English poor laws, Jones, P., and King, S. (eds) (Cambridge Scholars 2015); Elizabeth Hurren, 'Migration, settlement and the New Poor Law in England and Wales 1870s-1900" in Migration, settlement and belonging in Europe, 1500-1930s: comparative perspectives, King, S., and Winter, A. (eds) (Berghahn Books 2013). ${ }^{12}$ Samantha Shave, "'Great inhumanity": scandal, child punishment and policymaking in the early years of the New Poor Law workhouse system' (2018) 33 Continuity and Change 339.

${ }^{13}$ Ellen Barlee, Friendless and Helpless (Emily Faithful 1863) Page 210.

${ }^{14}$ Florence Davenport Hill, Children of the State (Macmillan 1889) Page 7.

15 Jean S. Heywood, Children in Care: The developments of the service for the deprived child (Routledge \& Kegan Paul 1965) Page 67.

${ }^{16}$ Harry Hendrick, Child Welfare: England 1872-1989 (Routledge 1994) Page 75.

${ }^{17}$ Elementary Education Act 1870 s.74 (Vict. 33 \& 34 c.75).

${ }^{18}$ Elementary Education Act 1876 s.4 (Vict. 39 \& 40 c.79) Elementary Education Act 1880 s.2-4 (VIct. 43 \& 44 c. 23).

${ }^{19}$ Elementary Education Act 1891 s.8 (Vict. 54 \& 55 c.56).

${ }^{20}$ Elementary Education Act 1876 s.10.

${ }^{21}$ The Local Government Board: Seventh Annual Report 1877-78 (C ( $2^{\text {nd }}$ series))

${ }^{22}$ Henry Fawcett M.P., Pauperism: Its Causes and Remedies (Macmillan \& Co 1871).

${ }^{23}$ The Poor Law Board: Twenty-third Annual Report 1870-71 (C $\left(1^{\text {st }}\right.$ series $\left.)\right)$ Page 207.

${ }^{24}$ Tufnell, 'Education of Pauper Children'.

${ }^{25}$ The Poor Law Board Twenty-third Annual Report 1870-71 (C ( $2^{\text {nd }}$ series)) Page 206.

${ }^{26}$ The Local Government Board: Second Annual Report 1872-73 (C ( $2^{\text {nd }}$ series)) Page 90.

${ }^{27}$ Note that classification status allowed the authorities to identify the children at risk of having their parent discharge them into the parent's care (parental discharge) once this became a critical issue.

${ }^{28}$ The Poor Law Board: Twenty-third Annual Report 1870-71 (C ( $2^{\text {nd }}$ series)) Page 207.

${ }^{29}$ Dr Bridges, 'Table showing Influx and Efflux of Casuals' in Menella Bute Smedley (ed), Boarding-Out and Pauper Schools Especially for Girls Being a Reprint of the Principal Reports on Pauper Education in the Blue Book for 1873-4 (Henry S King \& Co 1875) Pages 30-39.

30 Jane Nassau Senior, 'Education of Girls in Pauper Schools' in Menella Bute Smedley (ed), BoardingOut and Pauper Schools Especially for Girls Being a Reprint of the Principal Reports on Pauper Education in the Blue Book for 1873-4 (Henry S King \& Co 1875) Pages 59-66.

${ }^{31}$ Nassau Senior, 'Education of Girls in Pauper Schools' Page 60.

32 Davenport Hill, Children of the State Pages 315-324; Dr Bridges, 'Table showing Influx and Efflux of Casuals', in Menella Bute Smedley (ed), Boarding-Out and Pauper Schools Especially for Girls Being a 
Reprint of the Principal Reports on Pauper Education in the Blue Book for 1873-4 (Henry S King \& Co 1875) Page 30.

${ }^{33}$ The Poor Law Board: Twenty-third Annual Report 1870-71 (C (1st series)) Page 207.

${ }^{34}$ Dr Bridges, 'Table showing Influx and Efflux of Casuals' Pages 30.

${ }^{35}$ Dr Bridges, 'Table showing Influx and Efflux of Casuals' Pages 31.

${ }^{36}$ Dr Bridges, 'Table showing Influx and Efflux of Casuals' Pages 31.

${ }^{37}$ The Local Government Board: Fourth Annual Report 1874-1875 (C ( $2^{\text {nd }}$ series)) Page 195.

${ }^{38}$ Florence Davenport Hill, Children of the State (Macmillan 1889) Page 311.

${ }^{39}$ John Mundella M.P., Report of the Departmental Committee Appointed by the Local Government Board to Inquire into the Existing Systems for the Maintenance and Education of Children Under the Charge of the Board of Guardians (C ( $2^{\text {nd }}$ Series 1897) Pages $72-80$

${ }^{40}$ Dr Bridges, 'Table showing Influx and Efflux of Casuals' Pages 30.

${ }^{41}$ Poor Law Act 1889 Vict. 52 \& 53 c.56 (hereafter PLA 1889).

${ }^{42}$ PLA 1889 s. 1

${ }^{43}$ PLA 1889 s.1(3).

${ }^{44}$ The Local Government Board: Nineteenth Annual Report 1889-1890 (C ( $2^{\text {nd }}$ series)) Page 53.

${ }^{45}$ Custody of Children Act 1891 s.3(b) (Vict. 54 c.3)

${ }^{46}$ Poor Law Act 1899 s.1(1). (Vict. 61 \& 62 c.60).

47 The York Herald, 'Yorkshire Poor Law Unions Conference at Harrogate', British Library Newspapers Part II: 1800-1900 11999 (1889) Page 6.

${ }^{48}$ The York Herald, 'Yorkshire Poor Law Unions Conference at Harrogate', British Library Newspapers Part II: 1800-1900 11999 (1889) Page 6.

${ }^{49}$ London, England, Poor Law and Board of Guardian Records 1430-1930, Board of Guardians; Register of Children Sent to South Metropolitan School District, 1884-1889; Reference Numbers: CABG/202/001; CABG/202/002 (hereafter PLBG, Reference Numbers: CABG/202/001; CABG/202/002).

${ }^{50}$ Mundella Report of the Departmental Committee Page 74.

${ }^{51}$ Mundella Report of the Departmental Committee Page 4.

${ }^{52}$ Mundella Report of the Departmental Committee Page 10.

${ }^{53}$ PLBG, Reference Numbers: CABG/202/001; CABG/202/002.

${ }^{54}$ PLBG: Reference Numbers: CABG/202/001; CABG/202/002.

${ }^{55}$ PLBG: Reference Numbers: CABG/202/001; CABG/202/002.

${ }^{56}$ See data about the triggers for poor law intervention for a sample of 150 children admitted to the SMSD between 1884-89 in Pimm-Smith, 'Juvenile de-pauperisation' Page 236.

${ }^{57}$ PLBG: Reference Numbers: CABG/202/001; CABG/202/002.

${ }^{58}$ The Poor Law Board: Twenty-third Annual Report 1870-71 (C (1st series)) Page 35.

${ }^{59}$ PLBG: Reference Numbers: CABG/202/001; CABG/202/002.

${ }^{60}$ PLBG: Reference Numbers: CABG/202/001; CABG/202/002.

${ }^{61}$ The Local Government Board: Nineteenth Annual Report $1889-90$ (C ( $2^{\text {nd }}$ series)) Page 15.

${ }^{62}$ PLBG: Reference Numbers: CABG/202/001; CABG/202/002.

${ }^{63}$ London Metropolitan Archives; London, England; Reference Number: SMSD/159; Film Number: X100/073.

${ }^{64}$ PLBG: Reference Number: CABG/202/001; Page 32.

${ }^{65}$ UK Census Collection for England and Wales 1881; Class: RG11; Piece: 690; Folio: 9; Page: 11; GSU roll: 1341160 .

${ }^{66}$ PLBG: Reference Number: $C A B G / 202 / 002$, Page 10.

${ }^{67}$ PLBG: Reference Number: $C A B G / 202 / 002$, Page 10.

${ }^{68}$ PLBG: Reference Number: $C A B G / 202 / 002$, Page 11.

${ }^{69}$ The family was traced to later census record using a method called genealogical triangulation. This method allows poor law sources to be connected to non-poor law sources by matching identification information between multiple sources (e.g. SMSD logbook next of kin information + a baptismal record + a census record) UK Census Collection for England and Wales 1891; Class: RG12; Piece: 806; Folio: 6; Page: 7; GSU roll: 6095916; UK Census Collection for England and Wales 1911; Class: RG14; Piece: 5147; Schedule Number: 227; England \& Wales, Civil Registration Marriage Index, 1837-1915; vol 2b; Page 541.

${ }^{70}$ The Poor Law Board: Twenty-third Annual Report 1870-71 (C (1st series)) Page 207. 
${ }^{71}$ The Local Government Board: Nineteenth Annual Report 1889-90 (C $\left(2^{\text {nd }}\right.$ series $\left.)\right)$ Page 349.

${ }^{72}$ The Local Government Board: Nineteenth Annual Report 1889-90 (C $\left(2^{\text {nd }}\right.$ series)) Page 161.

${ }^{73}$ Hansard, 2 Aug 1894 vol 339, cols 161-169.

${ }^{74}$ PLBG: Reference Numbers: CABG/202/001; CABG/202/002.

${ }^{75}$ The Local Government Board: First Annual Report 1871-1872 (C ( $2^{\text {nd }}$ series)) Pages XXXIV-V.

${ }^{76}$ PLBG: Reference Numbers: CABG/202/001; CABG/202/002.

${ }^{77}$ Nassau Senior, 'Education of Girls in Pauper Schools' Page 60.

${ }^{78}$ PLBG: Reference Numbers: CABG/202/001; CABG/202/002.

${ }^{79}$ PLBG: Reference Numbers: CABG/202/001; CABG/202/002; CABG/202/003.

${ }^{80}$ Murdoch, Imagined Orphans Pages 137-184.

${ }^{81}$ Charles Booth, Life and Labour in London; Maps of London Poverty Districts and Streets (Macmillan 1902) Descriptive Map of London Poverty 1889. South-Eastern Sheet comprising the registration districts of St. Saviour's and St. Olave's, Southwark, and parts of Lambeth, Camberwell, and Greenwich. Coordinates G 10.

${ }^{82}$ Gordon Road Workhouse Admissions, 1880-1881, Reference Number: CABG/176 and LEBG/1891/1; UK Census Collection for England and Wales 1881; Class: RG11; Piece: 1788; Folio: 26; Page: 29; GSU roll: 1341432.

${ }^{83}$ London Metropolitan Archives; London, England; Reference Number: SMSD/160; Film Number: X100/082; London Metropolitan Archives; London, England; Reference Number: SMSD/159; Film Number: X100/073; PLBG: Reference Number: CABG/202/002, Page 18.

${ }^{84}$ UK Census Collection for England and Wales 1881; Class: RG11; Piece: 694; Folio: 88; Page: 28; GSU roll: 1341161.

${ }^{85}$ London Metropolitan Archives; London, England; Church of England Parish Registers, 1754-1931; Reference Number: Page 73/emm/020.

${ }^{86}$ PLBG: Reference Number: CABG/202/002, Page 18.

${ }^{87}$ UK Census Collection for England and Wales 1891; Class: RG11; Piece: 694; Folio: 88; Page: 28; GSU roll: 1341161; Class: RG12; Piece: 1407; Folio: 22; Page: 14; GSU roll: 6096517.

${ }^{88}$ Nassau Senior, 'Education of Girls in Pauper Schools' Page 60.

${ }^{89}$ Nassau Senior, 'Education of Girls in Pauper Schools' Page 60; PLBG: Reference Numbers: CABG/202/001; CABG/202/002; CABG/202/003.

${ }_{90}$ London Metropolitan Archives; London, England; Reference Number: SMSD/160; Film Number: X100/082.

${ }^{91}$ London Metropolitan Archives; London, England; Reference Number: SMSD/161; Film Number: X100/082.

92 London Metropolitan Archives; London, England; Reference Number: SMSD/161; Film Number: X100/082; London Metropolitan Archives; London, England; Reference Number: SMSD/162; Film Number: X100/083.

${ }^{93}$ London Metropolitan Archives; London, England; Reference Number: SMSD/162; Film

Number: X100/083; London Metropolitan Archives; London, England; Reference Number: SMSD/186; Film Number: X100/086.

${ }^{94}$ London Metropolitan Archives; London, England; Reference Number: SMSD/187; Film Number: X100/087; London Metropolitan Archives; London, England; Reference Number: SMSD/162; Film Number: X100/083.

${ }_{95}^{95}$ UK Census Collection for England and Wales 1901; Class: RG13; Piece: 651; Folio: 113; Page: 52.

${ }^{96}$ Jersey Heritage; St Helier, Jersey; Jersey Parish Registers; Reference Number: G/C/03/A2/18; UK Census Collection for England and Wales 1881-1901; Class: RG11; Piece: 688; Folio: 54; Page: 13; GSU roll: 1341160; The National Archives of the UK (TNA); Kew, Surrey, England; Census Returns of England and Wales, 1891; Class: RG12; Piece: 484; Folio: 64; Page: 7; GSU roll: 6095594; Class: RG13; Piece: 651; Folio: 113; Page: 52.

${ }^{97}$ London Metropolitan Archives; London, England; School Admission and Discharge Registers; Reference: LCC/EO/DIV07/SUM/AD/001.

${ }^{98}$ London Metropolitan Archives; London, England; School Admission and Discharge Registers; Reference: LCC/EO/DIV07/COM/AD/009.

${ }^{99}$ London, England, TS Exmouth Training Ship Records, 1876-1918; 20 Sep 1893.

${ }^{100}$ London Metropolitan Archives; London, England; School Admission and Discharge Registers; Reference: LCC/EO/DIV07/CHO/AD/010. 
${ }^{101}$ UK Census Collection for England and Wales 1901; Class: RG13; Piece: 651; Folio: 113; Page: 52. 